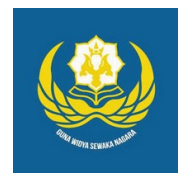

Jurnal Analogi Hukum

Journal Homepage: https://ejournal.warmadewa.ac.id/index.php/analogihukum

\title{
Status Hukum Akta Jual Beli Hak Milik Atas Tanah Bersertifikat yang Telah Dibatalkan Pengadilan Tata Usaha Negara
}

\author{
Kadek Indra Yuda*, I Nyoman Putu Budiartha dan Desak Gde Dwi Arini \\ Fakultas Hukum, Universitas Warmadewa, Denpasar-Bali, Indonesia \\ *indrayuda@gmail.com
}

\begin{abstract}
How To Cite:
Yuda, K. I., Budiartha, I. N. P.,\& Arini, D. G. D. (2020). Status Hukum Akta Jual Beli Hak Milik Atas Tanah Bersertifikat yang Telah Dibatalkan Pengadilan Tata Usaha Negara. Jurnal Analogi Hukum. 2(2). 228-233. Doi: https://doi.org/10.22225/ah.2.2.1898.228-233
\end{abstract}

\begin{abstract}
Buying and selling land is one of the legal acts that can cause the transfer of land rights from the hand of the seller to the buyer. The transition of land rights must be registered based on the evidence of the relevant deed. If traced from the beginning, there is a real buying and selling land arising based on an agreement or approval that is set in the form of a covenant between the seller and the buyer. Based on the background of this research problem is: how the existence of land-Buy sales certificate handled by PPAT certificate was cancelled and how the legal sanctions on Dibatalkannya legal status of PPAT deed in the purchase and Sale of land. The type of research used is empirical legal research. The results of the discussion in this study are: the existence of land purchase certificate that issued PPAT certificate was cancelled because PPAT is State Administration officer, in the event of a dispute, BPN is responsible for the certificate that has been Issued. PPAT has never come into contact with the TUN judiciary relating to the treaty Deed of ownership of the land. Guidelines for creating a certificate of land ownership in BPN. If the certificate is cancelled, the party that is won shall apply for the cancellation of the certificate to BPN, and juridically the PPAT deed that has been registered to the land Office is automatically null and void. Legal sanctions against the legal status of PPAT certificates and the sale of land, which have the same consequences as the unlawful act is only a violation of the law can be resolved through a public court, not Can be resolved through the State Administrative Court.
\end{abstract}

Keywords: Buying and Selling Land, Certificates at Cancel, PTUN

\begin{abstract}
Abstrak - Jual beli tanah adalah salah satu perbuatan hukum yang bisa menyebabkan terjadinya peralihan hak atas tanah dari tangan penjual ke tangan pembeli. Peralihan hak atas tanah itu harus didaftarkan dengan berdasarkan bukti akta yang bersangkutan. Kalau ditelusuri sejak awal, adanya jual beli tanah sesungguhnya timbul berdasarkan pada suatu kesepakatan atau persetujuan yang dituangkan dalam bentuk perjanjian antara pihak penjual dengan pihak pembeli. Berdasarkan latar belakang rumusan masalah penelitian ini yaitu: bagaimana keberadaan sertifikat jual beli tanah yang ditangani PPAT sertifikatnya dibatalkan dan bagaimana sanksi Hukum atas dibatalkannya status hukum Akta PPAT dalam pembelian dan penjualan tanah. jenis penelitian yang dipergunakan adalah penelitian hukum empiris.Hasil pembahasan dalam kajian ini yaitu: keberadaan sertifikat jual beli lahan yang dikeluarkan PPAT sertifikatnya dibatalkan karena PPAT adalah Pejabat Tata Usaha Negara, ketika terjadi sengketa, BPN bertanggung jawab terhadap sertifikat yang telah dikeluarkan. PPAT tidak pernah bersentuhan dengan peradilan TUN kaitannya dengan akta perjanjian balik nama kepemilikan atas lahan. yang dijadikan pedoman untuk membuat sertifikat kepemilikan lahan di BPN. Apabila sertifikat tersebut dibatalkan, maka pihak yang dimenangkan mengajukan permohonan pembatalan sertifikat ke BPN, dan secara yuridis akta PPAT yang telah didaftarkan ke Kantor Pertanahan pun secara otomatis batal dan tidak sah. Sanksi Hukum terhadap batalnya status hukum sertifikat PPAT dalam pembelian dan penjualan lahan, mempunyai akibat yang sama dengan perbuatan yang melanggar hukum hanya saja perbuatan melanggar hukum tersebut dapat diselesaikan melalui pengadilan umum, tidak bisa diselesaikan melalui Pengadilan Tata Usaha Negara.
\end{abstract}

Kata Kunci: Jual Beli Tanah, Sertifikat Yang di Batalkan, PTUN

Jurnal Analogi Hukum, Volume 2, Nomor 2, 2020. CC-BY-SA 4.o License 


\section{Pendahuluan}

Hubungan manusia dengan tanah ibarat sisi mata uang yang tidak dapat dipisahkan, karena dalam kehidupan sehari-hari tanah selalu diperlukan baik itu dipergunakan untuk tempat tinggal maupun untuk dijadikan sebagai sarana, untuk memenuhi kebutuhan sandang, pangan,papan, dan kebutuhan yang sifatnya religius.Demikian juga halnya bagi bangsa Indonesia yang susunan kehidupan penduduknya termasuk perekonomiannya masih bercorak agraris, sebagian besar penduduk hidup dari hasil pertanian baik sebagai petani pemilik maupun sebagai petani penggarap.

Adanya aspek perjanjian dalam jual beli tanah menyebabkan terjadinya perikatan antara para pihak sehingga dengan demikian perbuatan jual beli tanah itu tunduk pada kaidah-kaidah hukum privat yaitu Hukum Perdata karena halhal yang berkaitan dengan perjanjian diatur didalamnya. Sedangkan menginjak pada proses kaidah-kaidah Hukum Perdata tetap sepenuhnya tunduk pada kaidah-kaidah Hukum Administrasi Negara. Terjadinya perbuatan tersebut menurut Boedi Harsono disebabkan oleh beberapa alasan yaitu (Harsono, 1999):

PPAT merupakan Pejabat Umum untuk memiliki wewenang dan tugas melaksanakan urusan pemerintah sebagaimana diuraikan dalam pasal 1 angka 1 Undang-undang No.5 tahun 1986, yang diwujudkan dengan pembuatan akta tanah sebagai bukti dan dasar dalam melaksanakan pendaftaran peralihan hak atas tanah.

Disamping itu PPAT merupakan Pejabat yang berada dibawah naungan kementerian Agraria/Pertanahan (Ketua BPN) yang diberi wewenang dan tugas seperti telah diuraikan diatas ia berkedudukan sebagai Badan atau Pejabat Tata Usaha Negara.

Dengan demikian dalam hal ini PPAT membuat akta tanah ini berarti dalam hal ini terjadi norma kabur yaitu belum adanya aturan yang jelas yang mengatur tentang PPAT dalam membuat akta otentik. Di tambah lagi dengan adanya gugatan terhadap PPAT dalam jual beli tanah telah membawa suatu masalah baru pada Hukum Administrasi Negara khususnya berkaitan terhadap kompetensi absolut untuk mengadili dari PTUN. Hal tersebut terjadi karena jual beli tanah sesungguhnya tunduk pada Negara (PTUN). Hal tersebut karena jual beli tanah sesungguhnya tunduk pada tiga aspek hukum yang sangat berimpit yaitu Hukum perdata, Hukum Administrasi Negara dan
Hukum Agraria.

Pada penelitian sebelumnya, (Satriadiana, 2017) mengungkapkan kepastian hukum sertifikat pengganti hak milik atas tanah adalah sama dengan sertifikat hak milik atas tanah, sertifikat pengganti hak milik atas tanah dapat dibatalkan apabila cacat administrasi dan melaksanakan putusan Pengadilan Tata Usaha Negara yang telah berkekuatan hukum tetap, orang asing yang menguasai tanah yang telah diputuskan batal oleh PTUN yang telah berkekuatan hukum tetap, terhadap sertifikat hak milik atas tanah tersebut dinyatakan batal atau dapat dibatalkan dan tanah tersebut kembali ke Negara. Penelitian lainnya oleh (Ekasari, 2019), mengemukakan Kekuatan Putusan PTUN yang telah mempunyai kekuatan hukum tetap terhadap Pembatalan Sertifikat Hak Milik Atas Tanah merupakan kekuatan hukum yang mengikat semua orang (erga omnes) serta memiliki kekuatan pembuktian dan memiliki kekuatan hukum eksekutorial. Kekuatan hukum Surat Keputusan Pembatalan Sertifikat Hak Milik Atas Tanah yang dikeluarkan oleh Kepala Kantor Pertanahan mempunyai kekuatan eksekutorial/kekuatan untuk di jalankan sebagai tindak lanjut dari pelaksanaan putusan PTUN yang telah memperoleh kekuatan hukum tetap, yang Amarnya berkaitan dengan perintah pembatalan Sertifikat Hak Milik Atas Tanah.

Melihat dari uraian latar belakang diatas, permasalahan yang akan dianalisis dalam penelitian ini adalah kedudukan akta jual beli tanah yang dibuat PPAT sertifikatnya dibatalkan dan akibat Hukum atas pembatalan status hukum Akta PPAT dalam jual beli tanah.

\section{Metode}

Tipe metode yang dipakai adalah kajian hukum empiris sebab dalam kajian disamping berdasarkan teori-teori yang ada kemudian juga dibandingkan dengan penelitian berdasarkan wawancara dan data di lapangan. Dalam kajian ini digunakan pendekatan sosiologis, pendekatan perundang-undangan, pendekatan konseptual dan pendekatan kasus.

\section{Hasil dan Pembahasan}

\section{Kedudukan Akta Jual Beli Tanah Yang Dibuat PPAT Sertifikatnya Dibatalkan}

PPAT memiliki dua alternatif yaitu menolak atau mengabulkan, bilamana mengabulkan dibuatlah Akta dengan konstasi kata-kata: Demikianlah Akta ini dibuat dan seterusnya, jika menolak, penolakan tersebut 
diberitahukan secara tertulis kepada pihakpihak yang bersangkutan disertai alasannya. Hal ini sesuai dengan Putusan Pengadilan Tata Usaha Negara Nomor: 21/G/1999/PTUN.Dps.

Dalam kapasitasnya sebagai PTUN, PPAT bertugas dalam rangka pembuatan akta tanah tertentu sehingga ia dapat menolak atau mengabulkan permohonan yang bersangkutan. Hal ini mempunyai arti bahwa bila PPAT menolak permohonan itu maka ia tidak mengeluarkan akta tanah yang dimaksudkan, dan sebaliknya bila PPAT mengeluarkan akta tanah yang dimohonkan oleh pemohon maka secara otomatis berarti mengabulkan permohonan tersebut.

Tindakan PPAT yang mengabulkan atau menolak permohonan pembuatan akta tanah, menurut Boedi Harsono dapat dikatagorikan sebagai Keputusan Tata Usaha Negara, sesuai dengan pasal 1 angka 3 UU No. 5 tahun 1986. PPAT merupakan Pejabat umum yang diangkat dan diberhentikan oleh Menteri Agraria/ Pertanahan (Kepala BPN), yang diberikan tugas membantu sebagaian kegiatan Pemerintah khususnya Kepala Kantor Pertanahan untuk melaksanakan pendaftaran peralihan hak atas tanah (Prakoso, 1988).

PPAT merupakan Pejabat umum yang diangkat dan diberhentikan oleh Menteri Agraria/Pertanahan (Kepala BPN), yang diberikan tugas membantu sebagaian kegiatan Pemerintah khususnya Kepala Kantor Pertanahan untuk melaksanakan pendaftaran peralihan hak atas tanah. Dengan adanya tugas tersebut, PPAT diberikan suatu wewenang berdasarkan Peraturan Perundang-undangan yang berlaku untuk membuat akta tanah dalam rangka: Memindahkan hak atas tanah, Memberikan hak baru atas tanah, Menggadaikan tanah, Pemberian hak tanggungan atas tanah.

Berkaitan dengan wewenang dan tugasnya yang begitu penting dalam bidang Agraria/ pertanahan maka untuk dapat diangkat sebagai PPAT harus benar-benar mempunyai wawasan yang luas, mengenai Peraturan Perundangundangan yang berlaku, dan lulus ujian yang diadakan oleh Direktorat Jenderal Agraria atau kepala Badan Pertanahan, kecuali Camat diangkat sebagai PPAT karena jabatannya. Disamping itu untuk memperlancar pelaksanaan program pendaftaran tanah diseluruh Indonesia, Menteri Agraria/Pertanahan (Kepala BPN) juga mengangkat PPAT sementara dan khusus.

Sertifikat yang dikeluarkan oleh Badan Pertanahan Nasional (BPN) dapat dijadikan sebagai objek sengketa Tata Usaha Negara sepanjang dalam posita (fundamentum petendi) dan petitum dari gugatan penggugat bukan mengenai sengketa kepemilikan hak, melainkan Keputusan Pejabat/Badan Tata Usaha Negara, dalam hal ini BPN selaku Badan TUN yang mengeluarkan sertifikat a atas tanah. Sebagai contoh yaitu sengketa TUN yang diputus oleh Pengadilan TUN Semarang Putusan No.10/G/ TUN/2002/PTUN.SMG.

Dengan demikian sesuai dengan hasil wawancara penulis dengan Luh Putu Arya Setiti, yang berkedudukan di Jalan Jelantik No. 5 Kecamatan Gianyar Kabupaten Gianyar yang mengatakan bahwa: Ketika terjadi sengketa, BPN bertanggung jawab terhadap sertifikat yang telah dikeluarkan. PPAT tidak pernah bersentuhan dengan peradilan TUN kaitannya dengan akta perjanjian peralihan hak atas tanah (jual beli) yang dijadikan syarat untuk membuat sertifikat hak atas tanah di BPN. Apabila sertifikat tersebut dibatalkan, maka pihak yang dimenangkan mengajukan permohonan pembatalan sertifikat ke BPN, dan secara yuridis akta PPAT yang telah didaftarkan ke Kantor Pertanahan pun secara otomatis batal dan tidak sah. (Wawancara dengan Luh Putu Arya Setiti, pada tanggal 26 Juni 2019)

Dalam mengeluarkan suatu keputusan, Badan atau Pejabat Tata Usaha Negara harus memperhatikan ketentuan-ketentuan yang berlaku, sebab jika tidak diperhatian maka ada kemungkinan keputusan yang telah dikeluarkannya mengandung kekurangankekurangan sehingga keputusan tersebut tidak sah.

Indonesia adalah negara hukum yang mempunyai tujuan dan cita-cita yang sangat luhur seperti telah diuraikan dalam Pembukaan Undang-Undang Dasar 1845 alenia ke empat. Untuk mencapai tujuan dan cita-cita tersebut hukum memegang peranan yang sangat penting sebab melalui peraturan hukum tersebut setiap orang memperoleh suatu pedoman dalam bertingkah laku serta memperoleh suatu perlindungan terhadap hak-hak asasi yang dimilikinya.

Salah satu wujud pelindungan terhadap hak-hak asasi warga negara dari adanya kesewenang-wenangan aparatur negara telah terbukti dengan terbentuknya Undang-undang No. 5 Tahun 1986 tentang Peradilan Tata Usaha Negara. Terbentuknya Undang-undang No. 5 Tahun 1986 tersebut merupakan implementasi dari Undang-Undang No. 14 Tahun 1970 tentang Ketentuan-ketentuan Pokok Kekuasaan Kehakiman Khususnya pasal 10 ayat 1 yang 
menyatakan bahwa oleh pengadilan dan lingkungan Peradilan Umum, Peradilan Agama, Peradilan Militer, dan Peradilan Tata Usaha Negara melakukan Kekuasaan Kehakiman (Wargakusuma, 1995).

Peradilan Tata Usaha Negara merupakan suatu lembaga pelaksana kekuasaan kehakiman yang mempunyai tugas dan wewenang untuk memeriksa, memutuskan dan menyelesaikan sengketa dalam bidang Tata Usaha Negara (pasal 47 Undang-Undang No. 5 Tahun 1986). Yang dimaksud dengan sengketa Tata Usaha Negara menurut pasal 1 ayat 4 adalah sengketa antara seseorang atau Badan Hukum Perdata dengan Badan atau Pejabat Tata Usaha Negara baik dipusat maupun didaerah, mengakibatkan dikeluarkannya suatu Keputusan Tata Usaha Negara termasuk sengketa kepegawaian berdasarkan Peraturan Perundang-undangan yang berlaku.

Dari rumusan ketentuan tersebut dapatlah diketahui bahwa yang menjadi objek sengketa Tata Usaha Negara adalah Keputusan Tata Usaha Negara yang dikeluarkan oleh Badan atau Pejabat Tata Usaha Negara. Hal ini berarti bahwa wewenang dari Peradilan Tata Usaha Negara hanya sengketa-sengketa yang ditimbulkan oleh adanya Keputusan Tata Usaha Negara. Sedangkan untuk sengketa-sengketa yang lain yang timbul bukan karena Keputusan Tata Usaha Negara tidak termasuk dalam kompetensi Perasilan Tata Usaha Negara melainkan dapat diselesaikan melalui lembaga peradilan lain sebagaimana yang diuraikan dalam pasal 1 angka 3 Undang-Undang No. 5 Tahun 1986 telah ditentukan mengenai keputusan-keputusan yang tidak dapat dikategorikan sebagai Keputusan Tata Usaha Negara.

Pemindahan hak atas tanah menyebabkan hak atas tanah beralih kepada orang lain. Jika pemindahan di sini adalah perbuatan hukum yang disengaja dilakukan dengan tujuan agar hak atas tanah berpindah dari yang mengalihkan kepada yang menerima pengalihan.Pembuatan akta atas jual beli hak milik atas tanah, sebagaimana dimaksud dalam pasal 37 (1) dihadiri oleh para pihak yang bersangkutan dan disaksikan oleh sekurang-kurangnya 2 (dua) orang saksi yang memenuhi syarat untuk bertindak sebagai saksi dalam perbuatan hukum (Utrecht, 1986).

Dalam proses pembuatan akta jual beli hak milik atas tanah, para PPAT dan camat selaku pejabat pembuat akta tanah berada di bawah pengawasan Kepala Direktorat Agraria Sub Direktorat pendaftaran tanah dari daerah yang bersangkutan.

Berdasarkan pada uraian diatas, jika dikaitkan dengan PPAT dalam membantu Kepala Kantor Pertanahan dalam bidang pendaftaran peralihan hak atas tanah berdasarkan Peraturan Pemerintah No. 24 tahun 1997 tentang Peraturan Jabatan Pembuat Akta Tanah jelas tidak dapat digugat di Peradilan Tata Usaha Negara karena PPAT dalam melakukan tugas dan wewenangnya tidak dapat diklasifikasikan sebagai Keputusan Tata Usaha Negara, karena akta yang dibuat oleh PPAT merupakan kesepakatan antara kedua belah pihak yaitu antara penjual dan pembeli. PPAT hanya menuangkan ke dalam suatu akta, mengenai apa yang menjadi kesepakatan antara kedua belah pihak. Dalam Pasal 1868 menyatakan akta otentik, ialah suatu akta yang didalam bentuk yang ditentukan UU, dibuat dihadapan Pegawai-pegawai Umum, untuk itu ditempatkan dimana akta itu dibuatnya.

Pejabat Umum adalah orang yang diangkat dan diberhentikan oleh pemerintah diberi wewenang dan kewajiban untuk melayani publik dalam hal tertentu, dalam hal ini PPAT adalah pembuat akta otentik mengenai hak atas tanah atau hak milik atas satuan rumah susun. PPAT bukan Pejabat Tata Usaha Negara, sebab antara PPAT dengan pemerintah tidak ada hubungan dinas. Sebagaimana pendapat Logemen, bahwa hubungan dinas dengan negara ada, dimana orang mengikatkan diri dan rela diangkat dalam jabatan-jabatan tertentu dengan adanya suatu balas jasa berupa gaji dan keuntungan-keuntungan.

\section{Akibat Hukum Atas Pembatalan Status Hukum Akta PPAT Dalam Jual Beli Tanah}

Dalam mengeluarkan suatu keputusan, Badan atau Pejabat Tata Usaha Negara harus memperhatikan ketentuan-ketentuan yang berlaku, sebab jika tidak diperhatikan maka ada kemungkinan keputusan yang telah dikeluarkannya mengandung kekurangankekurangan sehingga keputusan tersebut tidak sah. Dalam pengajuan gugatan tersebut tentunya berdasarkan alasan-alasan yang kuat antara lain adanya penyalahgunaan wewenang, keputusan itu bertentangan dengan peraturan Perundang-undangan yang berlaku dan lain sebagainya. Setelah melakukan pemeriksaan terhadap pokok sengketa sebagaimana tertuang dalam gugatan Badan atau Pejabat Tata Usaha Negara, maka Pengadilan Tata Usaha Negara akan mengeluarkan Amar Putusan.

Setelah 3 (tiga) bulan sejak Putusan 
Pengadilan tersebut diberitahukan kepada Badan atau Pejabat Tata Usaha Negara tersebut ternyata kewajibannya tidak dilaksanakan, maka penggugat mengajukan permohonan kepada Ketua Pengadilan yang bersangkutan agar memerintahkan Badan atau Pejabat Tata Usaha Negara untuk melaksanakan putusan tersebut. Sesudah Badan atau Pejabat Tata Usaha Negara itu diperintahkan oleh Ketua Pengadilan untuk melaksanakan putusan tersebut, ternyata juga tidak mau melaksanakan putusan yang dimaksudkan, maka Ketua Pengadilan mengajukan hal ini kepada instansi Badan atau Pejabat Tata Usaha Negara menurut jenjang jabatannya (Adjie, 2009).

Dua bulan sesudah instansi atasan Badan atau Pejabat Tata Usaha Negara yang bersangkutan menerima pemberitahuan dari Ketua Pengadilan, harus telah memerintahkan kepada Badan atau Pejabat Tata Usaha Negara itu untuk melaksanakan Putusan Pengadilan tersebut, (Pasal 116 Undang-undang No.5 tahun 1986). Jika dengan keterlibatan instansi atasan yang bersangkutan juga tidak melaksanakan Putusan pengadilan maka perlu adanya keterlibatan Presiden sebagai Kepala Pemerintah, yang pertanggungjawaban dalam membina setiap pelaksanaan urusan pemerintah.

Bertitik tolak uraian itu jika dikaitkan dengan tindakan PPAT yang menolak atau mengabulkan permohonan pembuatan akta tanah dan juga akta yang telah dikeluarkannya jelas tidak dapat digugat ke Peradilan Tata Usaha Negara, karena tindakan itu dan akta yang dibuat oleh PPAT bukan merupakan Keputusan Tata Usaha Negara dengan Nomor : 136/B/TUN/2000/PT.TUN.SBY. Oleh karena itu untuk menyelesaikan masalah yang terjadi haruslah melalui Pengadilan Umum. Disini penulis lebih sependapat dengan Putusan No.136/B/TUN/2000/PT.TUN.SBY yang mana akta jual beli No.211/1999 tanggal 15 september 1999 atas tanah sertifikat hak milik No. 4072/Desa Kuta atas nama Ida Ayu Durupadi adalah sah. Karena akta jual beli yang menjadi sengketa diterbitkan berdasarkan adanya kehendak dan kesepakatan antara kedua belah pihak, hal ini jelas sebagai perbuatan hukum dibidang hukum perdata.

Perbuatan hukum yang telah dilakukan oleh para pihak seperti jual beli tanah akan mengakibatkan akibat hukum yang sesuai dengan Peraturan Perundang-undangan yang berlaku. Disamping itu apabila PPAT yang bersangkutan terbukti melakukan pelanggaran berat seperti pemalsuan atas akta tertentu sebagaimana diuraikan dalam Peraturan
Pemerintah No.24 tahun 1997 maka ia diberhentikan secara tidak terhormat dari jabatannya bahkan dapat dituntut secara Pidana dengan ancaman hukuman kurungan atau penjara selama-lamanya 5 tahun atau lebih berat berdasarkan Putusan pengadilan yang sudah mempunyai kekuatan hukum tetap.

\section{Simpulan}

Berdasarkan uraian tersebut diatas dapatlah ditarik simpulan sebagai berikut: Kedudukan akta jual beli tanah yang dibuat PPAT sertifikatnya dibatalkan karena PPAT adalah Pejabat Tata Usaha Negara, ketika terjadi sengketa, BPN bertanggung jawab terhadap sertifikat yang telah dikeluarkan. PPAT tidak pernah bersentuhan dengan peradilan TUN kaitannya dengan akta perjanjian peralihan hak atas tanah (jual beli) yang dijadikan syarat untuk membuat sertifikat hak atas tanah di BPN. Apabila sertifikat tersebut dibatalkan, maka pihak yang dimenangkan mengajukan permohonan pembatalan sertifikat ke BPN, dan secara yuridis akta PPAT yang telah didaftarkan ke Kantor Pertanahan pun secara otomatis batal dan tidak sah.

Sanksi Hukum atas pembatalan status hukum sertifikat PPAT dalam penjualan dan pembelian tanah, mempunyai akibat yang sama dengan perbuatan yang melanggar hukum hanya saja perbuatan melanggar hukum tersebut dapat diselesaikan melalui pengadilan umum, tidak bisa diselesaikan melalui Pengadilan Tata Usaha Negara.

\section{Daftar Pustaka}

Adjie, H. (2009). Sanksi Perdata \& Administratif Terhadap Notaris sebagai Pejabat Publik (Cetakan Pertama). Bandung: Refika Aditama.

Ekasari, L. P. H. (2019). Kekuatan Putusan Pengadilan Tata Usaha Negara yang Berkekuatan Hukum Tetap Terhadap Pembatalan Sertifikat Hak Milik Atas Tanah Melalui Kewenangan Kepala Kantor Pertanahan. Jurnal Hukum Prasada, 6(1), 22-35. Retrieved from http://dx.doi.org/10.22225/ jhp.6.1.1006.22-35

Harsono, B. (1999). Hukum Agraria Indonesia. Jakarta: Djambatan.

Prakoso, D. (1988). Peradilan Tata Usaha Negara. Yogyakarta: Liberty.

Satriadiana, I. D. P. (2017). Analisis Hukum Putusan Pengadilan Tata Usaha Negara 
Mataram Nomor 52/G/2010/Ptun.Mtr

Terhadap Pembatalan Sertifikat

Pengganti Hak Milik Atas Tanah.

Jurnal IUS (Kajian Hukum Dan

Keadilan), 5(2), 190-200. Retrieved

from http://dx.doi.org/10.29303/

ius.v5i2.447

Utrecht, E. (1986). Hukum Pidana I. Yogyakarta: Universitas Muhammadiyah. Retrieved from https://onesearch.id/Record/ IOS3680.16605

Wargakusuma, H. (1995). Hukum Agraria I. Jakarta: PT Gramedia Pustaka Utama. 